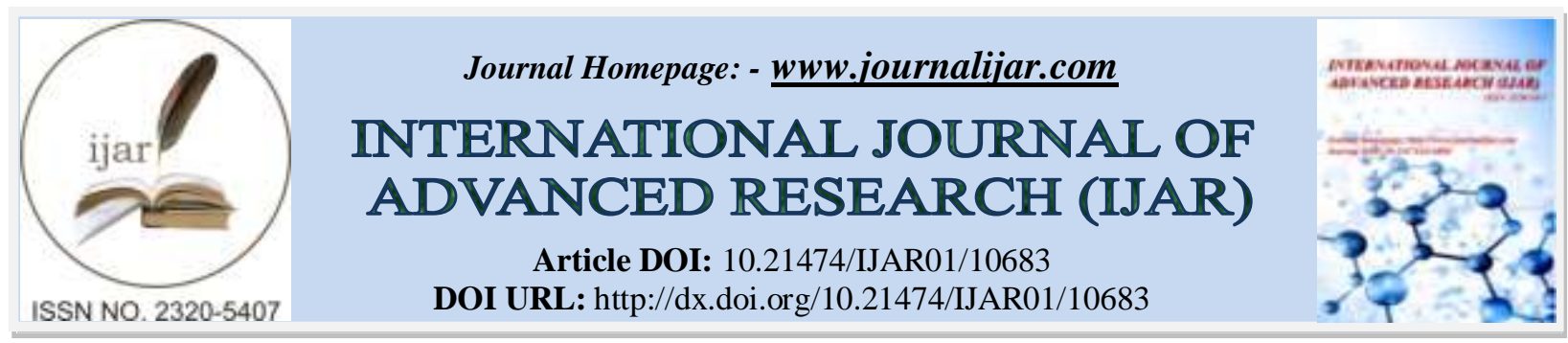

RESEARCH ARTICLE

\title{
PHYTOHEMAGGLUTINATION ASSAY OF CAMELLIA SINENSIS AND CAMELLIA ASSAMICA EXTRACTSON MEMBRANE RECEPTORS OF ERYTHROCYTE SURFACES
}

\section{Rajkumar S.D. ${ }^{1}$, Balasundar Gade ${ }^{1}$, Goutham Polisetty ${ }^{1}$, Keerthan Muttineni ${ }^{1}$ and Aprith Singh Chawla ${ }^{2}$ \\ 1. Department of Biotechnology, KLEF, Vaddeswaram, Guntur District, Andhra Pradesh, India. \\ 2. Department of Bioengineering and Technology, Gauhati University, Assam, India.}

\section{Manuscript Info}

………………….

Manuscript History

Received: 17 January 2020

Final Accepted: 20 February 2020

Published: March 2020

Key words:-

Camellia Sinensis, Camellia Assamica,

Erythrocytes, Glycoprotein,

Agglutination

\section{Abstract}

The objective of this study is a comparative analysis of the changes observed on the red blood cell antigens which differ in a short glycoprotein chain difference, by the effects of a Camellia sinensisand Camellia assamica extracts. The heamatological effect of the extract was prepared and evaluated using blood group analysis on haematological indices.Agglutination was clearly observed initially for $5 \mathrm{~min}$ for all the eight blood types. Specifically, for the O+ blood group there is a time lag for agglutination to take place for the incubation period of $15 \mathrm{~min}$ for C. sinensis, while agglutination occurred after 10 minutes of adding blood group antibodies with C. assamica. These results, as well as the possibility of adapting this method to a fully automated system, could be an important contribution to the field of immunohematology.

Copy Right, IJAR, 2020,. All rights reserved.

\section{Introduction:-}

$\mathrm{ABO}$ and $\mathrm{RhD}$ variants are the most studied blood group in India. ${ }^{[3]}$ Progress is being made towards modification of red blood cell surface antigens from $\mathrm{A}$ and/or B to blood group $\mathrm{O} .{ }^{[6]}$ In present study, we have been undertaken to explore the effect of Camellia sinensisand Camellia assamicaextract towards modification of red blood cell surface antigens. ${ }^{[19]}$ Plants are universally recognized as a vital part of the world's natural heritage and up to $80 \%$ of the population rely on plants for their primary healthcare. ${ }^{[5,21]}$ Varieties of medicinal plants are recognized as a source of natural antioxidants that can protect from oxidative stress, ${ }^{[7]}$ thus playing an important role in chemoprevention of diseases.Each of these plants has some effecton the endothelium, ${ }^{[9]}$ blood cells ${ }^{[1]}$ angiogenesis, ${ }^{[2,4]}$ cellular proliferation, ${ }^{[13]}$ vasculardynamics ${ }^{[18]}$ and cell mediators. ${ }^{[16,}{ }^{17]}$ The chemical composition of the leaves indicates the presence of polyphenols, which have antioxidant properties.Erythrocytic membrane instability is possibly a major factor as has been earlier reported with ethanol and chloroquine for the cytotoxicity of these plant extracts. ${ }^{[20]}$ Research findings suggest that anthocyanin extracts in a plant play a role in both stabilizing the red blood cell membrane and inhibiting polymerization of hemoglobin. ${ }^{[1]}$ This provides a possible molecular basis for earlier reports on the anti-sickling properties of anthocyanins from some plants and their use in the management of disease by traditional healers. ${ }^{[15]}$ 


\section{Material and Methods:-}

Preparation of Smoothie:

Extraction was carried out by grinding seeds of the plant with a pestle and mortar in the presence of liquid nitrogen and or made into smoothie ${ }^{[20]}$. The material was transferred to a vial and $500 \mu 1$ of lysis buffer (HiMedia) was added and the sample was vortexed. Later, the suspension was mixed for one hour at $37^{\circ} \mathrm{C}$ and filtered. The filtrate was spin at 14,000 rpm (Thermo, MicroCL 21 Microcentrifuge) in cold conditions for $10 \mathrm{~min}$ and supernatant was removed and stored at $4^{0} \mathrm{C}$ until further analysis.

\section{Blood sample collection and processing:}

Blood samples were obtained from eight healthy individuals (males and females) aged 18 to 20 years. Informed consent was obtained from everyone before collection of blood, and the procedures followed were in accordance with the ethical recommendations (23/IEC/IG/2017) of our institution ${ }^{14}$. The samples were kept at $4{ }^{0} \mathrm{C}$ and divided into groups, based on blood typing, using ABO diagnostic kit (Span Diagnostics). ${ }^{[10]}$

\section{Chemical analysis of extract:}

The alcoholic extract showed the presence of flavonoid, phenolics, glycoside, saponins, alkaloid, and polysaccharide when subjected to qualitative chemical tests. ${ }^{[8]}$ The total phenolic contents estimated were done according to standard published method FolinCiocalteu reagent.Aluminum chloride colorimetric method was used for flavonoid determination. ${ }^{[12]}$

\section{Determination of blood type conversion:}

Briefly, whole-blood cells from A, B, and O blood donated from healthy volunteers were loaded on agglutination plate. $5 \mu \mathrm{L}$ of the Anti-A or Anti-B or Anti-D antibodies were added to human A- or B-type whole-blood cells on a white acryl plate, and the agglutination reaction was determined within 30 s of its onset. ${ }^{[14]}$

\section{Results:-}

Blood sample collection and processing:

All the samples collected from the informed consent have been processed and analyzed for its type. The blood was collected into a vacuum glass tubeor heparin tubes used as anticoagulantfor the determination of blood group. All eight samples were processed and analyzed using ABO diagnostic kit (Span) and represented in table 1.

Table1:- ABO blood typing of various samples collected from volunteers.

\begin{tabular}{|l|l|l|}
\hline Sample ID & Age & Blood type \\
\hline KLEF01 & 21 & A+ \\
\hline KLEF02 & 20 & A- \\
\hline KLEF03 & 19 & B + \\
\hline KLEF04 & 18 & B- \\
\hline KLEF05 & 21 & AB+ \\
\hline KLEF06 & 20 & AB- \\
\hline KLEF07 & 18 & O+ \\
\hline KLEF08 & 20 & O- \\
\hline
\end{tabular}

\section{Chemical analysis of extract:}

Total phenolic and flavonoid contents were found about $13 \%$ and $3 \%$ respectively in the extract of Camellia sinensisand Camellia assamica. Total phenolic content was determined according to Folin-Ciocalteau method. The concentration of phenoliccompounds in test samples was calculated from the standard gallic acid curve. The standards graph of gallic acid and quercetin for total phenolic and flavonoid contents are shown in figures 1 and 2 respectively. 


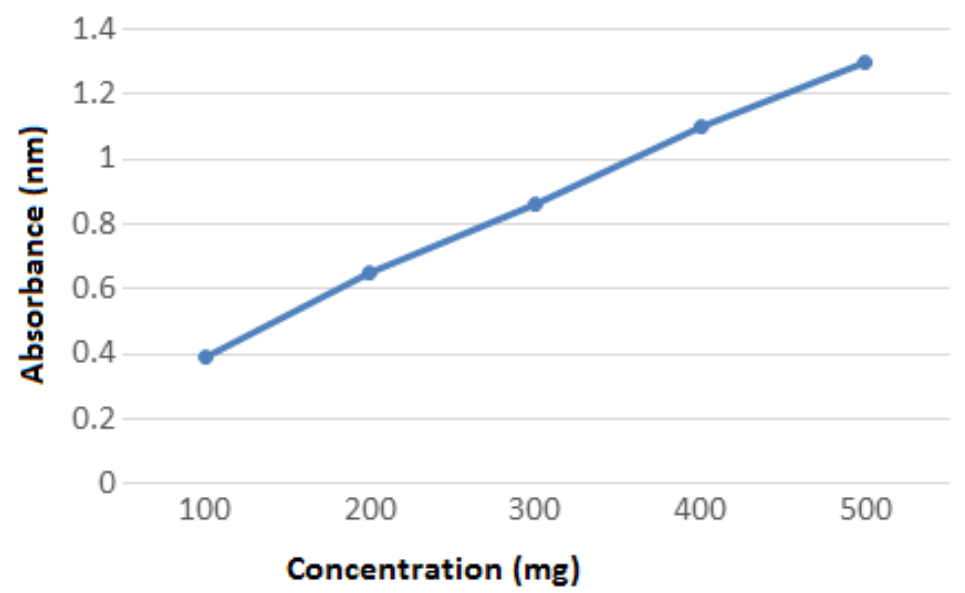

Figure 1:- Standard curve of gallic acid for total phenolic contents.

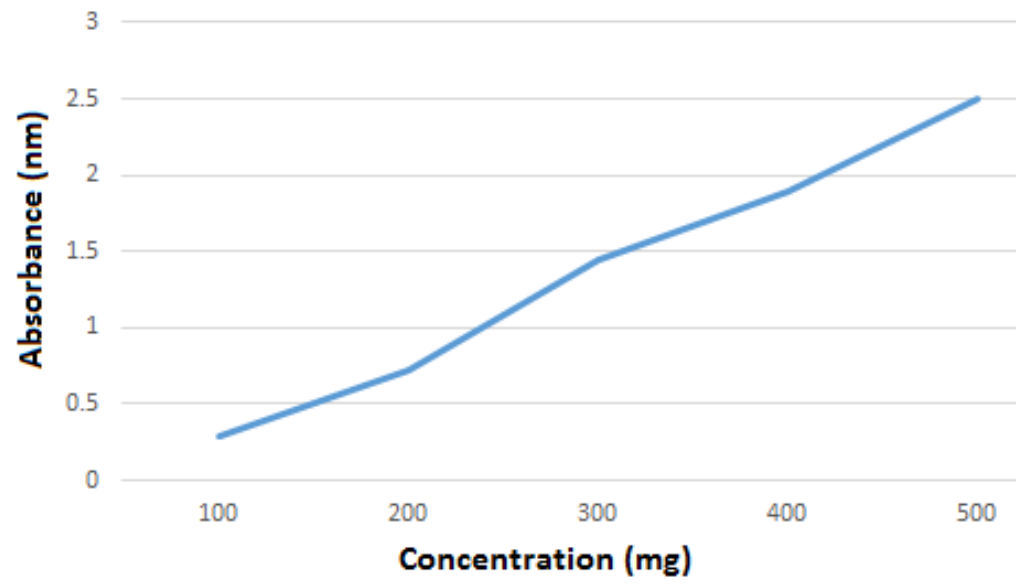

Figure 2:- Standard curve of quercetin for total flavonoid contents.

\section{Determination of blood type conversion:}

Analysis was run in duplicates $(n=2)$ to verify the difference in the effect of extracts on blood samples.First, it is observed that there was no effect of different extracts of processing on the enzyme activities on blood group. Later for the increase in incubation time, the agglutination was gradually decreased. Specifically, for the O+ blood group there is a time lag for agglutination to take place for the incubation period for $15 \mathrm{~min}$ for Camellia sinensis, while agglutination occurred after 10 minutes of adding blood group antibodies with Camellia assamica (Figure 3-10).

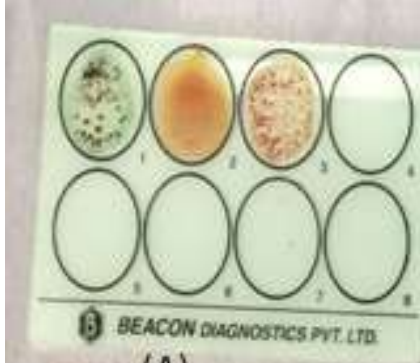

(A)

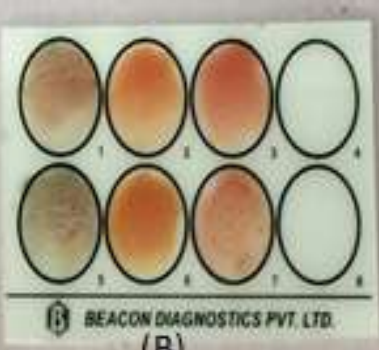

(B)

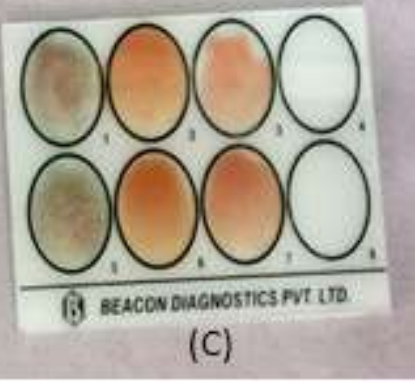

(C)

Figure 3:- Haemagglutination assay of RBCs by $\mathrm{ABO}$ slide method for blood type A+. (A) Agglutination was observed in zone 1 and 3 indicating the test as positive for blood type A+ (positive control test) (B) Agglutination of A+ blood type was hampered after incubating with Camellia sinensis, because zones were dark and uniform in color, indicating no agglutination. (C) Test is specific for Camellia assamicahowever, resulted in low level agglutination. 


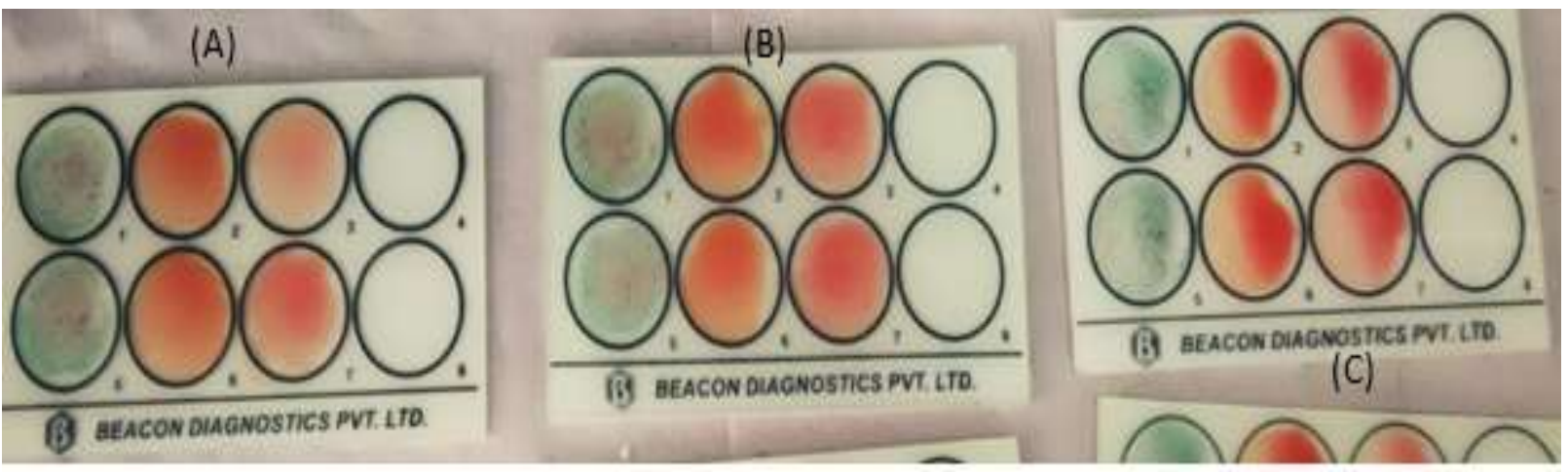

Figure 4:- Haemagglutination assay of RBCs by ABO slide method for blood type A-. (A) Agglutination was observed in zone 1 indicating the test as positive for blood type A- (positive control test) (B) Test is specific for Camellia sinensis, resulted in normal agglutination. (C) Test is specific for Camellia assamica, resulted in normal agglutination.
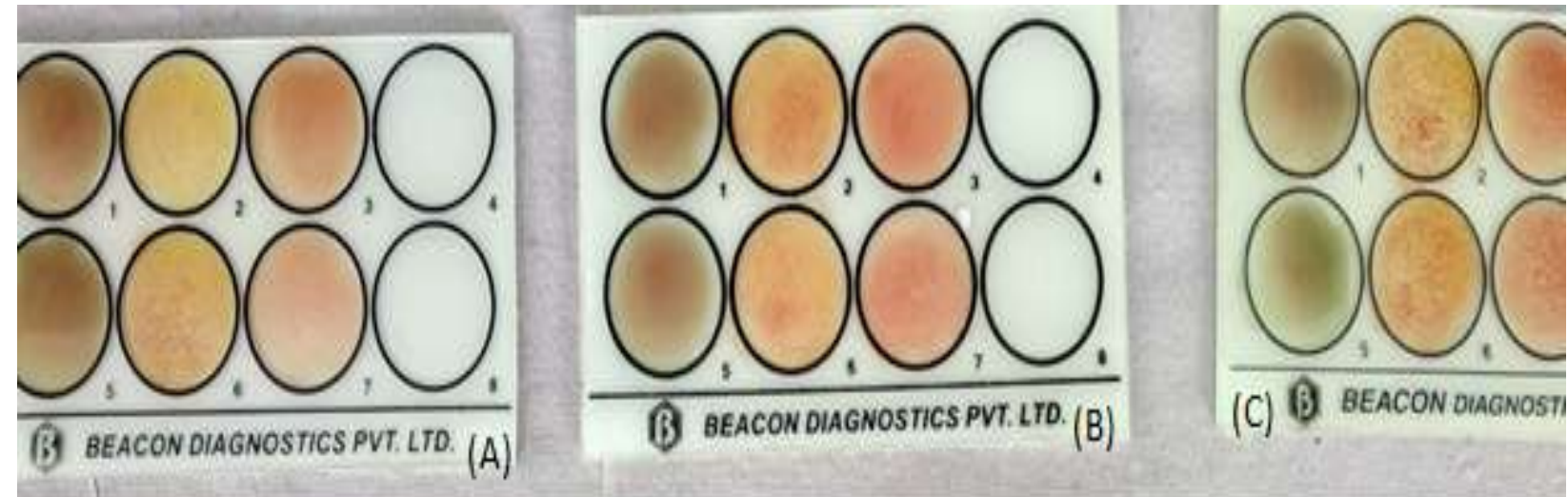

Figure 5:- Haemagglutination assay of RBCs by $\mathrm{ABO}$ slide method for blood type $\mathrm{B}+$. (A) Agglutination was observed in zone 2 and 3 indicating the test as positive for blood type B+ (positive control test) (B) Test is specific for Camellia sinensis, resulted in normal agglutination. (C) Test is specific for Camellia assamica, resulted in high level agglutination.

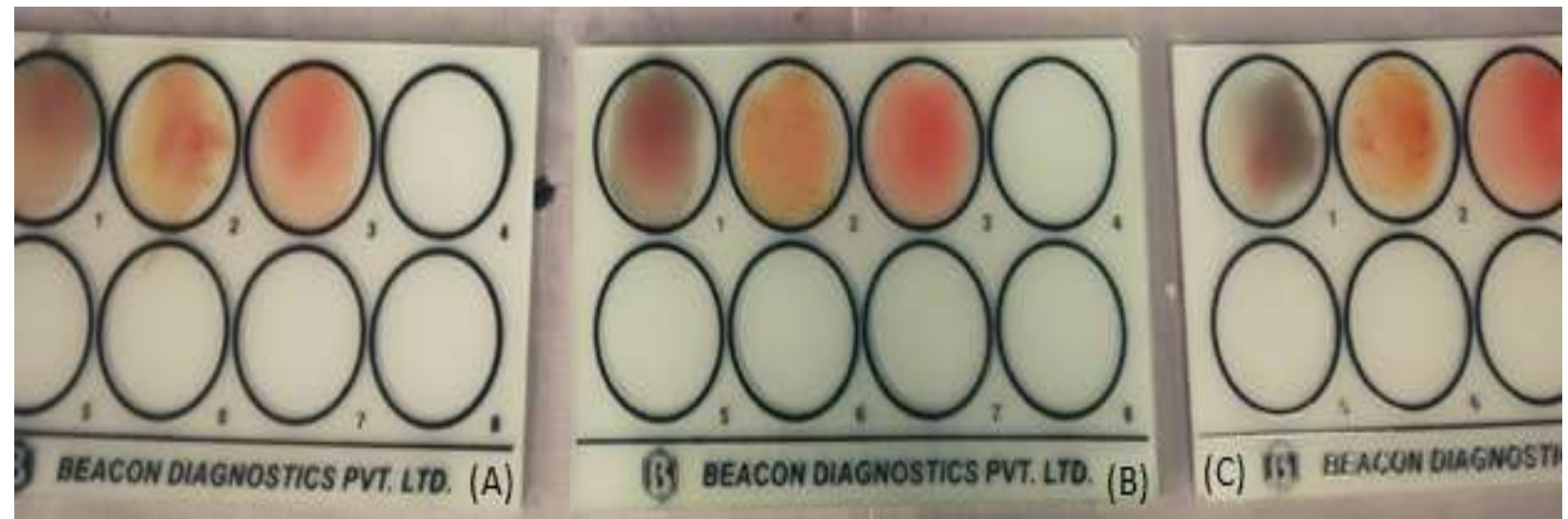

Figure 6:- Haemagglutination assay of RBCs by ABO slide method for blood type B-. (A) Agglutination was observed in zone 2 indicating the test as positive for blood type B- (positive control test) (B) Test is specific for Camellia sinensis, resulted in normal agglutination. (C) Test is specific for Camellia assamica, resulted in normal agglutination. 


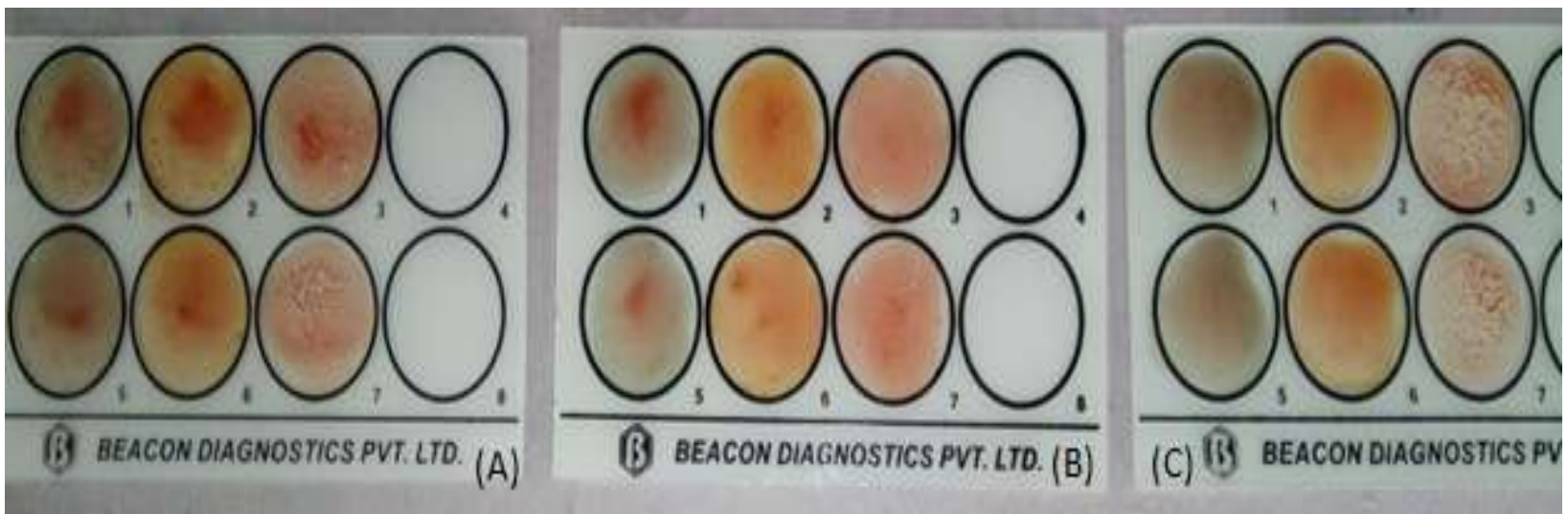

Figure 7:- Haemagglutination assay of RBCs by ABO slide method for blood type O+. (A) Agglutination was observed in zone 3 indicating the test as positive for blood type $\mathrm{O}+$ (positive control test) (B) Test is specific for Camellia sinensis, resulted in low level agglutination. (C) Test is specific for Camellia assamica, resulted in high level agglutination.

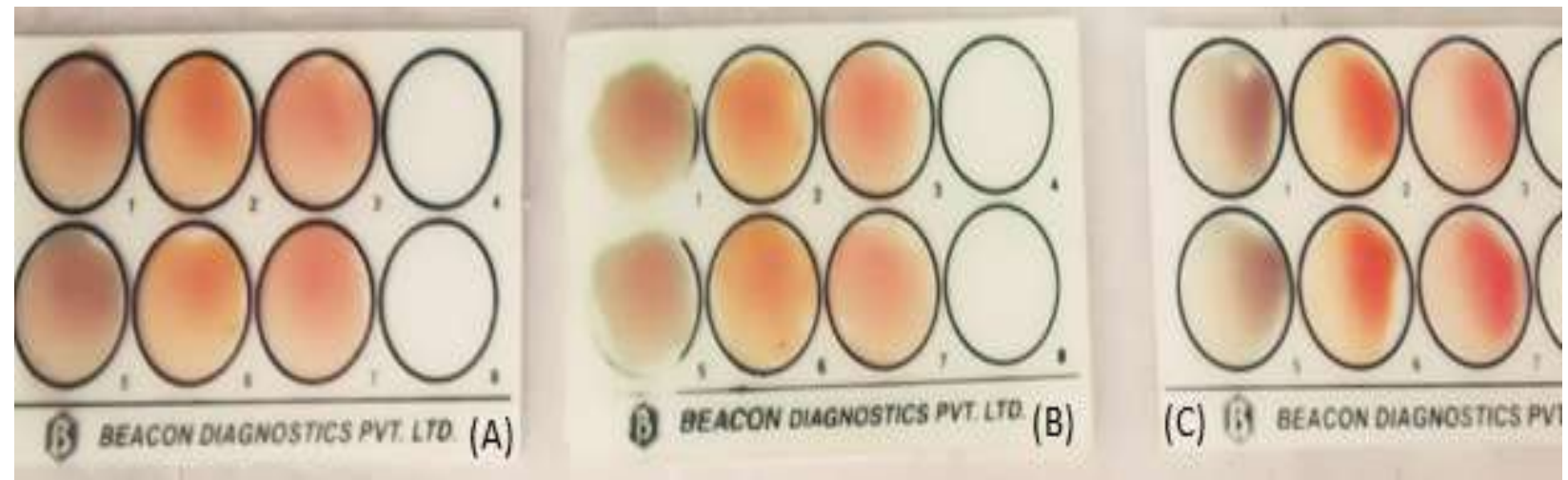

Figure 8:- Haemagglutination assay of RBCs by ABO slide method for blood type O-. (A) Agglutination was not observed in either zone 1, 2 or 3 indicating the test as positive for blood type O- (positive control test) (B) Test is specific for Camellia sinensis, resulted in nil agglutination. (C) Test is specific for Camellia assamica, resulted in nil agglutination.
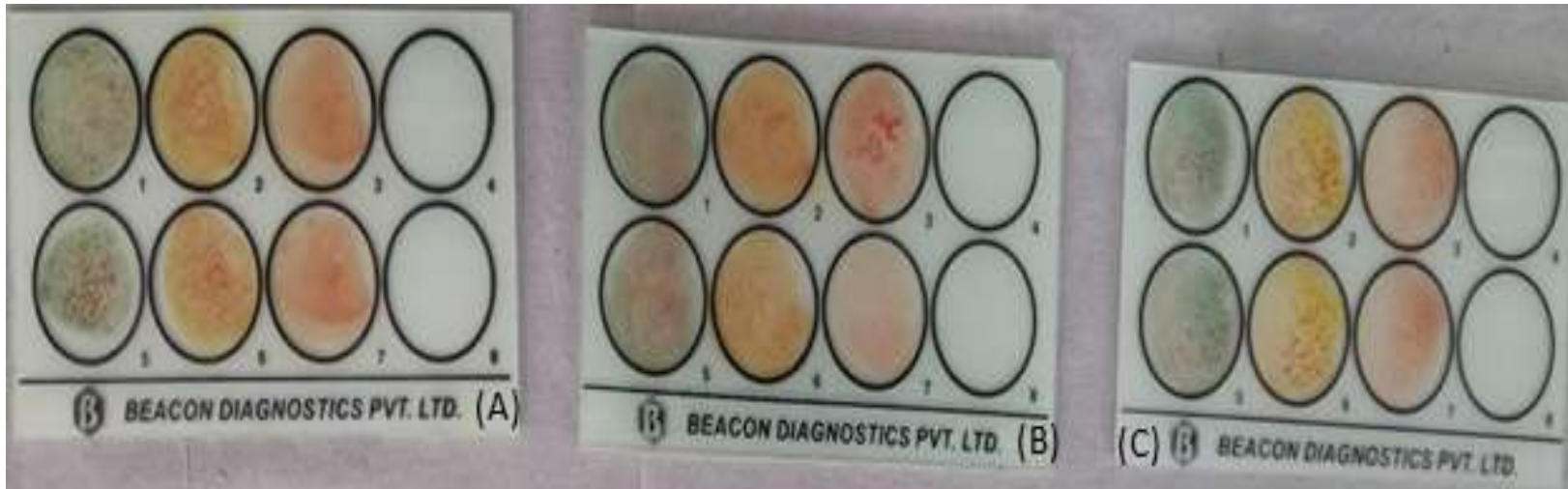

Figure 9:- Hemagglutination assay of RBCs by $\mathrm{ABO}$ slide method for blood type $\mathrm{AB}+$. (A) Agglutination was observed in zone 1, 2 and 3 indicating the test as positive for blood type $A B+$ (positive control test) (B) Test is specific for Camellia sinensis, resulted in normal agglutination. (C) Test is specific for Camellia assamica, resulted in high level agglutination. 

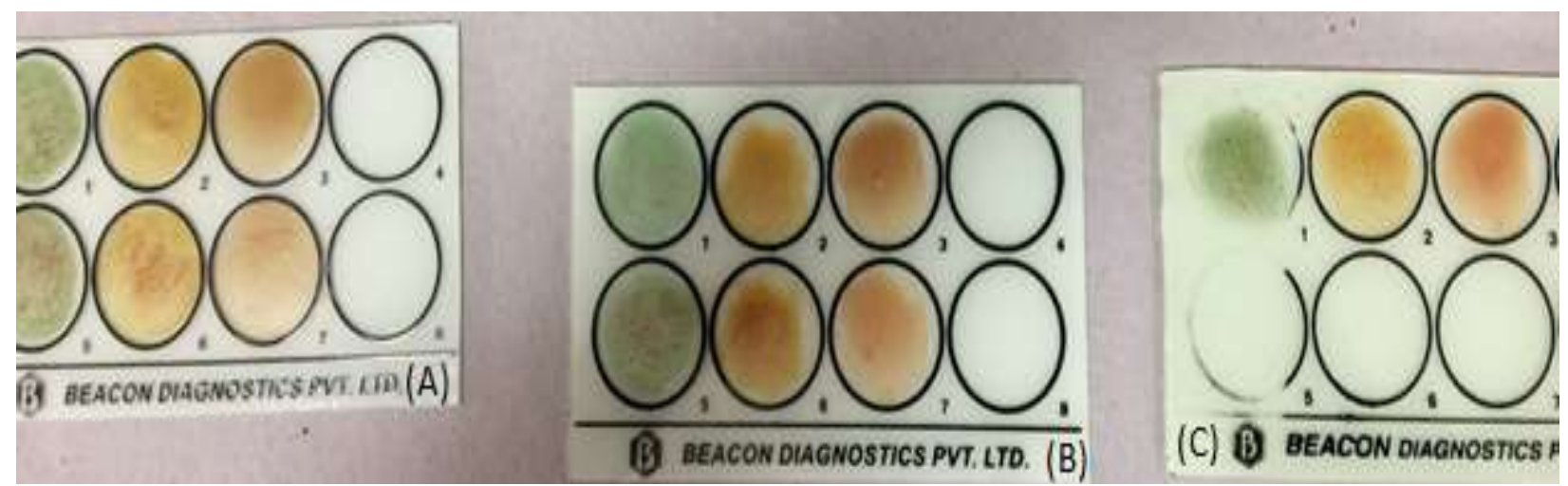

Figure 10:- Hemagglutination assay of RBCs by ABO slide method for blood type AB-. (A) Agglutination was observed in zone 1,2 and 3 indicating the test as positive for blood type AB- (positive control test) (B) Test is specific for Camellia sinensis, resulted in nil agglutination. (C) Test is specific for Camellia assamica, resulted in nil agglutination.

\section{Discussion:-}

The impact of the extracts on sample processing in the laboratory was evaluated for agglutination assays for $\mathrm{ABO}$ and $\mathrm{D}$ (Rh factor). For all the eight blood group samples agglutination initially for 30s was clearly seen for Camellia sinensisand Camellia assamicaat $0.05 \mathrm{mg} / \mathrm{mL}$. Haemagglutination assay of RBCs by ABO slide method for all eight blood types were evaluated and found to be effective for blood type B+ compared to other types. Although further work has to be extensively carried out to determine the effect of the coffee bean extracts at high incubation periods and also for high concentration levels.

\section{Conclusion:-}

Traditional blood typing methods are simple, sensitive and reliable, yet time consuming and labor intensive; moreover, the cost of blood group-specific antibodies is quite high. Hence an immediate approach for the modification of red blood cell antigens is needed for a compatible blood transfusion. Here, we have described a comparative study for effect of the extracts for haemagglutination detection on all types of blood groups. The difference between the extracts were evaluated and estimated to determine the modification of RBC surface antigen. The agglutinated samples elicited changes between $10 \%$ and $35 \%$ in the $\mathrm{O}+$ and $\mathrm{B}+$, while the non-agglutinated samples induced a maximum change of $7.5 \%$ in all other six blood types.

\section{Conflict of interest:}

The authors declare no conflict of interest.

\section{References:-}

1. Ainsworth EA, Gillespie KM. Estimation of total phenolic content and other oxidation substrates in plant tissues using Folin-Ciocalteu reagent. Nature protocols. 2007 Apr;2(4):875.

2. Almeida AA, Farah A, Silva DA, Nunan EA, Glória MB. Antibacterial activity of coffee extracts and selected coffee chemical compounds against enterobacteria. Journal of Agricultural and Food Chemistry. 2006 Nov 15;54(23):8738-43.

3. Anstee DJ. The relationship between blood groups and disease. Blood. 2010 Jun 10;115(23):4635-43.

4. Becker CG, Van Hamont N, Wagner M. Tobacco, cocoa, coffee, and ragweed: cross-reacting allergens that activate factor-XII-dependent pathways. Blood. 1981 Nov 1;58(5):861-7.

5. Chandra S, Chatterjee P, Dey P, Bhattacharya S. Evaluation of in vitro anti-inflammatory activity of coffee against the denaturation of protein. Asian Pacific Journal of Tropical Biomedicine. 2012 Jan 1;2(1):S178-80.

6. Dai J, Mumper RJ. Plant phenolics: extraction, analysis and their antioxidant and anticancer properties. Molecules. 2010 Oct 21;15(10):7313-52.

7. Garratty G, Telen MJ, Petz LD. Red cell antigens as functional molecules and obstacles to transfusion. ASH Education Program Book. 2002 Jan 1;2002(1):445-62.

8. Haibach F, Hata J, Mitra M, Dhar M, Harmata M, Sun P, Smith D. Purification and characterization of a Coffeacanephora $\alpha$-D-galactosidase isozyme. Biochemical and biophysical research communications. 1991 Dec 31;181(3):1564-71. 
9. Haque MR, Ansari SH, Rashikh A. Coffea arabica seed extract stimulate the cellular immune function and cyclophosphamide-induced immunosuppression in mice. Iranian journal of pharmaceutical research: IJPR. 2013;12(1):101.

10. Kumar Vemuri P, Veeravalli S. Expression, purification and characterization of human recombinant galectin 3 in Pichia pastoris. Iranian Journal of Biotechnology. 2014 Apr 1;12(2):3-11. Liu QP, Sulzenbacher G, Yuan H, Bennett EP, Pietz G, Saunders K, Spence J, Nudelman E, Levery SB, White T, Neveu JM. Bacterial glycosidases for the production of universal red blood cells. Nature biotechnology. 2007 Apr;25(4):454..

11. Nacharaju P, Acharya SA. Generation of universal red blood cells: an evaluation of various approaches. Recent Patents on Biomedical Engineering. 2008 Nov 1;1(3):171-9.

12. Nosál'ová G, Prisenžňáková L, Paulovičová E, Capek P, Matulová M, Navarini L, Liverani FS. Antitussive and immunomodulating activities of instant coffee arabinogalactan-protein. International journal of biological macromolecules. 2011 Nov 1;49(4):493-7.

13. Olsson ML, Hill CA, De La Vega H, Liu QP, Stroud MR, Valdinocci J, Moon S, Clausen H, Kruskall MS. Universal red blood cells - enzymatic conversion of blood group A and B antigens. Transfusion clinique et biologique. 2004 Feb 1;11(1):33-9.

14. Pourmorad F, Hosseinimehr SJ, Shahabimajd N. Antioxidant activity, phenol and flavonoid contents of some selected Iranian medicinal plants. African journal of biotechnology. 2006;5(11).

15. Seifried E, Klueter H, Weidmann C, Staudenmaier T, Schrezenmeier H, Henschler R, Greinacher A, Mueller MM. How much blood is needed? Vox sanguinis. 2011 Jan 1;100(1):10-21.

16. Tanaka K, Nishizono S, Tamaru S, Kondo M, Shimoda H, Tanaka J, Okada T. Anti-obesity and hypotriglyceridemic properties of coffee bean extract in SD rats. Food science and technology research. 2009;15(2):147-52.

17. Vaught JB. Blood collection, shipment, processing, and storage. Cancer Epidemiology and Prevention Biomarkers. 2006 Sep 1;15(9):1582-4.

18. Vemuri PK, Talluri B, Panangipalli G, Kadiyala SK, Veeravalli S, Bodiga VL. Purification and Identification of 20kDa protein from Parthenium hysterophorus. Int J Pharm Pharm Res. 2016;8:827-30.

19. Vemuri PK, Talluri B, Sharma A, Akkala G, Bodiga VL. Isolation and Characterization of a Lactose-Binding Lectin from Ocimum sanctum. Journal of Applied Pharmaceutical Science. 2015 Oct;5(10):113-7.

20. Vignoli JA, Bassoli DG, Benassi MT. Antioxidant activity, polyphenols, caffeine and melanoidins in soluble coffee: The influence of processing conditions and raw material. Food Chemistry. 2011 Feb 1;124(3):863-8. 